\title{
EFEKTIVITAS PENAMBAHAN VITAMIN C (ASCORBIC ACID) PADA PAKAN KOMERSIAL UNTUK PENGENDALIAN PENYAKIT KOI HERPESVIRUS (KHV) PADA IKAN MAS, Cyprinus carpio
}

\author{
Taukhid dan Angela Mariana Lusiastuti \\ Balai Riset Perikanan Budidaya Air Tawar \\ Jl. Raya Sempur No. 1, Bogor 16154 \\ E-mail: Iusiastuti@yahoo.com
}

(Naskah diterima: 26 Januari 2010; Disetujui publikasi: 19 November 2010)

\begin{abstract}
ABSTRAK
Riset dengan tujuan untuk mengevaluasi teknik pengendalian penyakit KHV pada ikan mas melalui penggunaan imunostimulan yaitu penambahan vitamin $\mathrm{C}$ pada pakan komersial dengan dosis yang berbeda telah dilakukan pada skala laboratorium. Perlakuan yang diterapkan adalah penambahan vitamin C jenis CFC-90 (microencapsulated vitamin C) pada pakan komersial dengan berbagai dosis yaitu: (A) tanpa vitamin C, sebagai kontrol, (B) vitamin C sebanyak $250 \mathrm{mg} / \mathrm{kg}$ pakan, (C) vitamin C sebanyak $500 \mathrm{mg} / \mathrm{kg}$ pakan, (D) vitamin C sebanyak $750 \mathrm{mg} / \mathrm{kg}$ pakan, dan (E) vitamin C sebanyak $1.000 \mathrm{mg} / \mathrm{kg}$ pakan. Masing-masing perlakuan dilakukan pengulangan sebanyak 3 (tiga) kali. Pada hari ke-15, seluruh kelompok perlakuan diinfeksi KHV secara buatan dengan teknik kohabitasi. Pengamatan dilakukan terhadap tingkah laku, gejala klinis, dan mortalitas ikan uji yang dilakukan setiap hari hingga akhir percobaan. Rataan persen sintasan ikan uji tertinggi pada akhir riset diperoleh pada penambahan vitamin C sebanyak $750 \mathrm{mg} / \mathrm{kg}$ pakan yaitu sebesar $82,22 \%$; diikuti dengan penambahan vitamin C $250 \mathrm{mg} / \mathrm{kg}$ pakan sebesar 70,00\%; vitamin C 1.000 $\mathrm{mg} / \mathrm{kg}$ pakan sebesar $61,11 \%$; vitamin C $500 \mathrm{mg} / \mathrm{kg}$ pakan sebesar $58,89 \%$; sedangkan rataan sintasan terendah diperoleh pada kelompok kontrol yaitu sebesar $27,78 \%$.
\end{abstract}

KATA KUNCI: vitamin C, dosis, KHV, ikan mas

ABSTRACT: The effectivity of the addition of ascorbic acid in commercial feed to control koi herpesvirus desease on carp, Cyprinus carpio. By: Taukhid and Angela Mariana Lusiastuti

Research with the aim to evaluate the technique of KHV disease control carp through the use of immunostimulatory namely the addition of vitamin $C$ in commercial diet with different doses have been performed in a laboratorial scale. The treatment applied was the addition of vitamin C of CFC-90 (microencapsulated vitamin C) in the commercial diet with different doses, namely: (A) without vitamin C, as control, (B) Vitamin C $250 \mathrm{mg} / \mathrm{kg}$ feed, (C) vitamin C of $500 \mathrm{mg} / \mathrm{kg}$ feed, (D) Vitamin C $750 \mathrm{mg} / \mathrm{kg}$ feed, and (E) of vitamin C as much as $1,000 \mathrm{mg} / \mathrm{kg}$ feed. Each treatment was repeated three times. On day $15^{\text {th }}$, all treatment groups were artificially infected with KHV using cohabitation techniques. Observations conducted to monitor behavior, clinical symptoms and mortality of fish tests were done every day until the end of the experiment. The highest mean percent of survival rate was recorded in treatment $D$ by adding vitamin C as much as $750 \mathrm{mg} / \mathrm{kg}$ of feed that was equal to $82.22 \%$, followed by the addition of vitamin C $250 \mathrm{mg} / \mathrm{kg}$ diets at $70.00 \%$ (treatment B), Vitamin C $1,000 \mathrm{mg} / \mathrm{kg}$ feed amounted to $61.11 \%$ (treatment E), vitamin C $500 \mathrm{mg} / \mathrm{kg}$ diets at 
$58.89 \%$ (treatment C), while the lowest average of survival rate was obtained in the control group that was equal to $27.78 \%$.

\section{KEYWORDS: vitamin $C$, dose, KHV, common carp}

\section{PENDAHULUAN}

Untuk mencegah terjadinya penyakit pada kegiatan budidaya, saat ini sudah dikembangkan beberapa metode, di antaranya probiotik atau persaingan antara faktor-faktor biologis. Alternatif yang sering dilakukan adalah vaksinasi atau indikasi kekebalan. Selain vaksin, juga dilakukan tindakan pemberian imunostimulan berupa vitamin C. Beberapa substansi diketahui mampu meningkatkan respon kekebalan seperti Lipopolisakarida dan $\beta$-Glukan (Scombes, 1994).

Vitamin C merupakan bahan yang dapat meningkatkan keragaan benih yang dapat berfungsi sebagai stimulan untuk sistem pertahanan tubuh non spesifik sehingga merupakan suatu komponen penting untuk meningkatkan kekebalan non spesifik (Scombes, 1994). Sedangkan vaksin adalah suspensi patogen hidup yang sudah dilemahkan atau dimatikan, bagian dari patogen atau substrat yang merupakan produk patogen yang bersifat antigenik, imunogenik, dan protektif apabila masuk ke dalam tubuh akan merangsang timbulnya antibodi (ab) yang menyebabkan ikan tahan terhadap patogen tersebut (Kamiso, 1996).

Ikan mas merupakan salah satu komoditas ikan pangan strategis, pemasok protein hewani bagi jutaan rakyat Indonesia, baik di pedesaan maupun di perkotaan. Direktorat Jenderal Perikanan Budidaya (2002) melaporkan bahwa produksi perikanan air tawar didominasi oleh jenis ikan mas, yaitu sebesar $46,5 \%$; dan Provinsi Jawa Barat menyumbangkan sekitar $60 \%$ dari total produksi ikan mas nasional. Terjadinya kasus kematian massal ikan mas akibat infeksi Koi Herpes Virus (KHV) di beberapa sentra budidaya sejak pertengahan tahun 2002, mengakibatkan produksi ikan mas mengalami penurunan sekitar $50 \%$ pada kurun waktu 2002-2004. Kerugian yang diakibatkan oleh penyakit tersebut pada akhir 2004 diperkirakan mencapai lebih dari 150 milyar rupiah. Berbagai upaya pengendalian telah dilakukan, antara lain melalui pembentukan posko penanggulangan wabah, sosialisasi sta- tus penyakit, sarasehan, penyaluran bantuan, dan lain-lain. termasuk pemberlakukan aturan khusus melalui Surat Keputusan Menteri Departemen Kelautan dan Perikanan No. 28/ Men/2002, No. 40/Men/2002, dan Permen No. 55/Men/2004.

KHV merupakan penyakit viral pada ikan mas dan koi (Cyprinus carpio) yang sangat menular, mengakibatkan mortalitas antara 80$100 \%$ dari populasi ikan, dengan masa inkubasi antara 1-14 hari. Individu yang bertahan hidup (survivors) sekitar $20 \%$ pada saat terjadi wabah umumnya akan menjadi tahan (resistant) terhadap infeksi berikutnya. Namun ketahanan tersebut tidak menunjukkan adanya transfer kepada keturunannya (maternal immunity).

Hingga kini belum tersedia teknologi pengendalian KHV yang memiliki tingkat keberhasilan dan kesesuaian tinggi untuk berbagai sistem budidaya ikan mas dan koi. Namun berdasarkan pengalaman selama ini, nampaknya strategi yang paling mungkin untuk pengendalian penyakit tersebut adalah melalui pendekatan ekologis dan biologis. Beberapa teknik pengendalian KHV pada ikan mas sudah dikembangkan, antara lain melalui pendekatan ekologis (manipulasi suhu air dan kandungan bahan organik terlarut), melalui pendekatan biologis (polikultur, induksi kekebalan spesifik melalui proses kohabitasi, serta penggunaan herbal terapi: ekstrak sambiloto dan daun pepaya).

Sejumlah materi biologis dan sintetis, atau lebih umum disebut imunostimulan telah diketahui memiliki potensi untuk meningkatkan ketahanan tubuh ikan. Vitamin C merupakan salah satu unsur yang berperan penting sebagai koenzim reaksi biokimia dalam tubuh, mencegah kelainan bentuk tulang, mencegah pengaruh negatif akibat gangguan lingkungan atau stress, dan meningkatkan ketahanan tubuh (Lim \& Lovell, 1978; Lovell, 1982; Navarre \& Halver, 1989; Ikeda, 1991), serta mempercepat proses penyembuhan luka (Jouncey et al., 1985; Ikeda, 1991). Pemberian vitamin $\mathrm{C}$ hingga dosis tertentu akan meningkatkan kesehatan ikan mulai dari perkembangan telur hingga dewasa, dan apabila 
kekurangan akan mengakibatkan penurunan kemampuan sintesa kolagen, sehingga mempengaruhi proses penyembuhan luka (Ikeda, 1991).

Riset ini bertujuan untuk mengevaluasi teknik pengendalian penyakit KHV pada ikan mas melalui penambahan vitamin $C$ pada pakan komersial dengan dosis yang berbeda.

\section{BAHAN DAN METODE}

\section{Wadah Uji dan Media Pemeliharaan}

Wadah yang digunakan adalah bak plastik volume 80 liter yang diisi air sebanyak 60 liter dan diisi ikan uji sebanyak 30 ekor. Air pemeliharan dilengkapi dengan aerasi yang diatur secara manual, sehingga diasumsikan masing-masing wadah memperoleh pasokan udara yang relatif sama. Pada masing-masing kelompok perlakuan, minimal sebanyak satu wadah dilengkapi dengan termometer minimum-maksimum yang di-reset setiap 24 jam.

Suhu air pemeliharaan selama berlangsungnya percobaan dipertahankan pada kisaran $23^{\circ} \mathrm{C}-27^{\circ} \mathrm{C}$. Pengaturan suhu air pada kisaran tersebut dilakukan dengan cara memasukkan es (terbungkus plastik) pada saat suhu air mulai pada posisi $26^{\circ} \mathrm{C}$, dan biasanya terjadi pada hari panas antara pukul 12.0015.00. Penggantian air pemeliharaan dilakukan setiap 7 hari sebanyak $25 \%$ dari total volume air. Selama proses uji tantang berlangsung, tidak dilakukan penggantian air hingga akhir percobaan.

\section{Ikan Uji}

Ikan mas uji yang digunakan berasal dari satu batch yang diperoleh dari pembudidaya ikan di sekitar Bogor-Sukabumi dengan ukuran berkisar antara 10-25 g/ekor. Kelompok ikan mas uji tersebut merupakan hasil pembenihan dari populasi induk ikan yang diyakini belum terinfeksi KHV. Konfirmasi status penyakit tersebut, apakah negatif atau positif terinfeksi KHV dilakukan sebelum kegiatan riset berlangsung melalui deteksi molekuler secara laboratoris dengan teknik Polymerase Chain Reaction (PCR) menurut metode Gray et al. (2002).

Jumlah pakan yang diberikan kepada ikan uji sebanyak $5 \%$ bobot biomassa per hari yang diberikan sebanyak 2 kali/hari yaitu pada pukul 08.00 dan 15.00. Sedangkan penyesuaian jumlah pakan yang diberikan dilakukan setiap 7 hari. Penambahan vitamin $C$ ke dalam pakan dilakukan secara konvensional dengan cara melekatkan vitamin C secara langsung beberapa saat sebelum diberikan kepada ikan uji. Pemberian vitamin C kepada ikan uji dilakukan setiap hari selama kegiatan riset berlangsung.

Pada hari ke-15, seluruh kelompok perlakuan diinfeksi KHV secara buatan dengan teknik kohabitasi. Pada masing-masing wadah percobaan, dimasukkan sebanyak 5 ekor ikan mas positif terinfeksi KHV. Populasi ikan mas sumber infeksi diperoleh dari pembudidaya/ pedagang ikan di sekitar Bogor-CianjurSukabumi, di mana sejarah atau gejala klinis populasi ikan tersebut pernah atau tengah terinfeksi KHV. Kepastian bahwa populasi ikan sumber infeksi tersebut positif terinfeksi KHV didasarkan pada batasan definisi kasus KHV menurut Taukhid et al. (2004), serta dikonfirmasi secara laboratoris melalui uji polymerase chain reaction (PCR).

\section{Perlakuan}

Perlakuan yang diterapkan pada riset ini adalah penambahan vitamin C jenis CFC-90 (microencapsulated vitamin C) pada pakan komersial dengan berbagai dosis penambahan, yaitu:

A. Pakan komersial tanpa penambahan vitamin C, sebagai kontrol

B. Pakan komersial dengan penambahan vitamin C sebanyak $250 \mathrm{mg} / \mathrm{kg}$

C. Pakan komersial dengan penambahan vitamin C sebanyak $500 \mathrm{mg} / \mathrm{kg}$

D. Pakan komersial dengan penambahan vitamin C sebanyak $750 \mathrm{mg} / \mathrm{kg}$

E. Pakan komersial dengan penambahan vitamin C sebanyak $1.000 \mathrm{mg} / \mathrm{kg}$

Masing-masing perlakuan dilakukan pengulangan sebanyak 3 (tiga) kali. Untuk mengetahui ada tidaknya pengaruh perlakuan terhadap sintasan ikan uji, digunakan uji F. Apabila dari hasil uji tersebut menunjukkan adanya perbedaan yang nyata, maka dilanjutkan dengan uji jarak berganda Duncan.

\section{Pengamatan dan Analisis}

Pengamatan dilakukan terhadap tingkah laku, gejala klinis, dan mortalitas ikan uji yang dilakukan setiap hari hingga akhir percobaan. Beberapa parameter kualitas air yang diduga memiliki peran sebagai stressor maupun 
patogenitas $\mathrm{KHV}$ seperti $\mathrm{pH}, \mathrm{O}_{2}, \mathrm{CO}_{2}$, alkalinitas, kesadahan, amoniak, nitrit, bahan organik terlarut, dan fosfat diamati secara serial, yaitu pada hari ke-0, 7, 14, 21, 28, dan 35 sedangkan suhu air minimum-maksimum diamati setiap hari.

Pengambilan sampel untuk deteksi keberadaan KHV pada ikan uji dengan teknik PCR dilakukan sesaat sebelum proses uji tantang, serta hari ke-7, 14, dan 21 setelah proses uji tantang. Jumlah sampel untuk keperluan deteksi KHV, masing-masing sebanyak 1 ekor/ wadah, sedangkan analisis PCR dilakukan secara pooling atau sampling dari masingmasing kelompok perlakuan. Untuk membedakan antara ikan uji yang diberi perlakuan dengan ikan sumber infeksi, maka spesimen ikan sumber infeksi diberi tag khusus yang dapat memastikan perbedaan dari kedua populasi ikan tersebut.

Analisis terhadap persen sintasan ikan uji setelah periode uji tantang dilakukan dengan menggunakan rancangan acak lengkap. Penentuan dosis vitamin C secara matematis yang memberikan hasil optimal terhadap sintasan hidup ikan uji dilakukan dengan metode polynomial-orthogonal. Sebagai baseline data, dilakukan pula analisis terhadap differential leucocyte pada darah ikan uji.

\section{HASIL DAN BAHASAN}

Visualisasi hasil deteksi KHV dengan teknik PCR terhadap populasi ikan mas yang digunakan sebagai hewan uji menunjukkan hasil negatif (Gambar 1), sedangkan populasi ikan mas yang digunakan sebagai sumber infeksi menunjukkan hasil positif (Gambar 2).

Berdasarkan visualisasi hasil deteksi KHV pada ikan mas yang ditunjukkan pada Gambar 1, maka penggunaan ikan uji dari populasi spesifik pathogen free terhadap KHV pada riset ini telah sesuai dengan persyaratan. Demikian pula dengan populasi ikan mas yang digunakan sebagai sumber infeksi seperti ditunjukkan pada Gambar 2, yang menunjukkan hasil positif $\mathrm{KHV}$; meskipun dengan persen prevalensi KHV hanya $80 \%$ (4/5). Namun karena pendekatan hasil deteksi adalah populasi; maka dapat

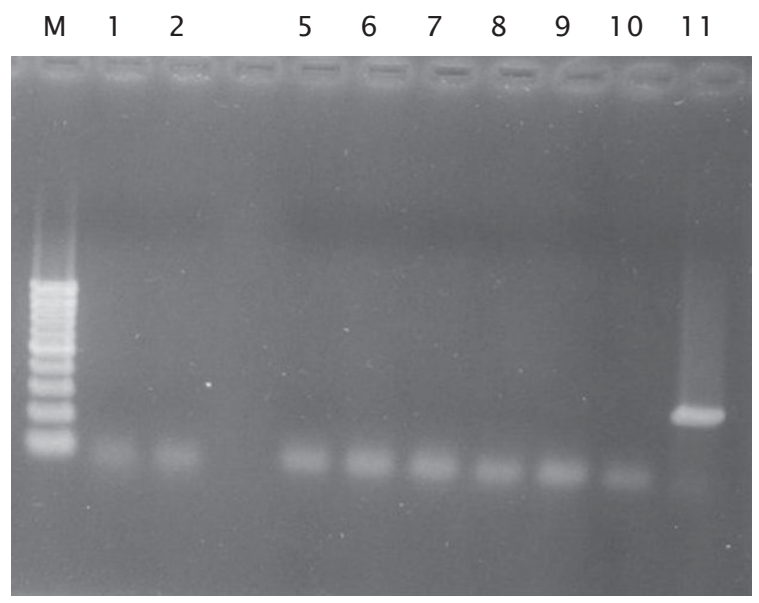

Gambar 1. Hasil deteksi KHV terhadap ikan mas uji pada saat plotting (line $1 \& 2$ ), dan setelah 7 hari perlakuan pemberian vitamin C (line 5-10). $M=$ marker DNA, line $1 \& 2$ = pooling sampel ikan mas uji, line $5-10=$ pooling sampel dari kelompok perlakuan A, B, C, D, E; dan line 11 = kontrol positif

Figure 1. Results of detection KHV on carp at the time of plotting of test (line 1 \& 2), and after seven days of treatment, vitamin C(line 50-10). M= marker DNA, line 1 \& $2=$ pooling sample test goldfish, line 50-10= pooling samples from treatment groups $A, B, C, D, E$, and line $11=$ positive control 


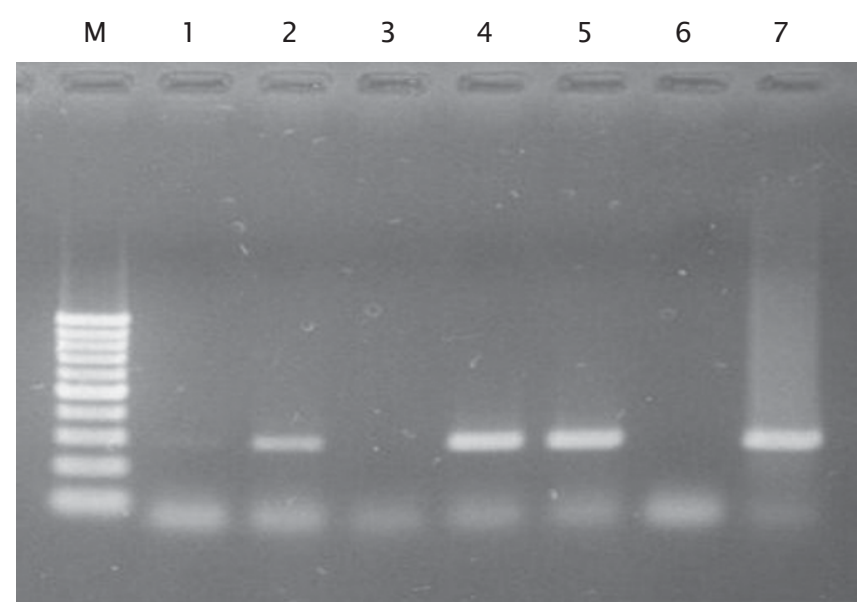

Gambar2. Hasil deteksi KHV terhadap ikan mas yang digunakan sebagai sumber infeksi sesaat sebelum proses kohabitasi. $M=$ marker DNA, line $1-5=$ sampel individu ikan mas, line $6=$ kontrol negatif dan line $7=$ kontrol positif

Figure 2. KHV detection results on carp were used as sources of infection shortly before the cohabitation. $M=$ marker DNA, the line 1-5= samples of individuals of common carp, line $6=$ negative control and the line $7=$ positive control

diasumsikan bahwa populasi ikan sumber tersebut adalah positif KHV.

Hasil infeksi buatan ikan uji terhadap infeksi KHV dengan teknik kohabitasi (mencampur ikan uji dengan ikan sumber infeksi), pada minggu ke-1 berlangsungnya proses uji tantang ditunjukkan pada Gambar 3. Pada gambar tersebut terlihat bahwa seluruh kelompok ikan uji menunjukkan hasil positif KHV, hal itu mengindikasikan bahwa proses infeksi buatan berhasil baik. Sedangkan hasil deteksi KHV pada minggu ke-2, diperoleh hasil positif KHV tampak jelas hanya pada kelompok perlakuan B dan C, sedangkan pada kelompok lainnya negatif KHV.

Deteksi KHV dengan teknik PCR terhadap sampel ikan mas uji yang dilakukan setiap minggu menunjukkan hasil yang kurang stabil, terutama mulai sampling pada minggu ke- 2 . Kondisi seperti ini mungkin disebabkan bahwa diagnosa PCR single step terhadap KHV terkadang belum memberikan hasil yang akurat bagi sampel dengan kondisi sub-klinis. Dari hasil diagnosa PCR ini juga mengindikasikan bahwa ikan mas yang tetap hidup setelah terinfeksi KHV, ternyata masih mengandung
KHV. Sehingga terhadap kelompok ikan survivors setelah terinfeksi KHV. Taukhid \& Suharni (2005) mengelompokkan populasi tersebut menjadi 3 katagori. Pertama, ikan survivor dari kasus KHV menjadi populasi yang kebal, bebas virus di dalam tubuhnya dan apabila terjadi wabah serupa, populasi tersebut akan tetap selamat karena memiliki antibodi spesifik hingga level protektif. Kedua, ikan survivor menjadi relatif kebal namun masih membawa (carriers) virus di dalam tubuhnya, dan tetap berpotensi untuk menularkannya ke populasi lain yang masih bebas tanpa mematikan dirinya. Ketiga, survivor menjadi pembawa dan tetap rentan terhadap KHV apabila ada pemicu yang mengakibatkan munculnya penyakit tersebut.

Mortalitas ikan uji mulai terjadi pada hari ke-5 dari saat diuji tantang, dan berlangsung hingga hari ke-17. Persentase mortalitas tertinggi terjadi pada hari ke-8 hingga hari ke13. Hal ini sesuai dengan pernyataan A bahwa masa inkubasi KHV berlangsung sekitar 14 hari, meskipun berdasarkan pengalaman selama ini masa inkubasi semakin pendek yaitu sekitar 7 hari. Rataan persen sintasan ikan uji tertinggi pada akhir riset diperoleh pada penambahan 


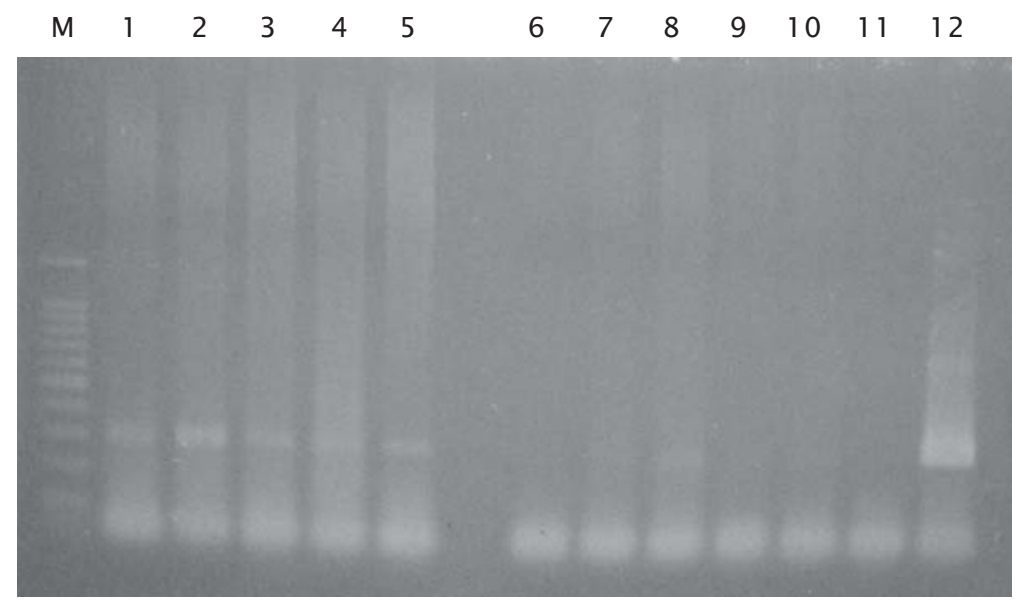

Gambar 3. Hasil deteksi Koi Herpes Virus (KHV) terhadap ikan mas uji pada minggu ke-1 \& 2 pasca pemberian infeksi buatan. $M=$ marker DNA, line 1-5= perlakuan A, B, C, D, E (minggu I), line 6$10=$ perlakuan $A, B, C, D, E$ (minggu II), $11 \& 12=$ kontrol negatif dan positif

Figure 3. Koi Herpes Virus detection results (KHV) on carp test at week $1 \& 2$ after administration of artificial infection. $M=$ marker $D N A$, the line 1-5= treatment $A, B, C, D, E$ (week I), line 6-10= treatment $A, B, C, D, E$ (second week), $11 \& 12=$ control negative and positive

vitamin C sebanyak $750 \mathrm{mg} / \mathrm{kg}$ pakan yaitu sebesar $82,22 \%$; sedangkan rataan sintasan terendah diperoleh pada kelompok kontrol yaitu sebesar $27,78 \%$. Nilai rataan persen sintasan ikan uji selengkapnya disajikan pada Tabel 1, dan pada Gambar 4 ditunjukkan histogram dari nilai-nilai tersebut. Analisis statistik terhadap persen sintasan kumulatif menunjukkan bahwa terdapat perbedaan yang nyata pada selang kepercayaan $95 \%(\mathrm{P}<0,05)$ antar kelompok perlakuan. Sedangkan hasil uji lanjutan diperoleh hasil seperti terlihat pada notasi di Tabel 1.

Kematian yang terjadi pada seluruh kelompok perlakuan mengindikasikan bahwa KHV merupakan penyakit yang ganas. Menurut OATA (2001), KHV merupakan penyakit viral pada ikan mas dan koi (Cyprinus carpio) yang sangat menular, mengakibatkan mortalitas antara $80 \%-100 \%$ dari populasi ikan, dengan masa inkubasi antara 1-14 hari. Adanya perbedaan rataan persentase sintasan yang signifikan antar kelompok perlakuan menunjukkan bahwa terdapat pengaruh positif akibat penambahan vitamin $C$ pada pakan yang berperan dalam meningkatkan status kesehatan ikan uji, dalam hal ini kekebalan non-spesifik. Apabila dibandingkan dengan kelompok kontrol, maka penambahan vitamin $\mathrm{C}$ memberikan hasil yang lebih baik terhadap sintasan ikan uji; dan dosis vitamin $\mathrm{C}$ yang memberikan nilai terbaik didapatkan pada konsentrasi $750 \mathrm{mg} / \mathrm{kg}$ pakan.

Nilai rataan sintasan yang lebih tinggi pada kelompok perlakuan membuktikan bahwa vitamin C dapat berfungsi sebagai materi biologis yang mampu mereduksi kasus KHV pada ikan mas, meskipun mekanisme dari kondisi tersebut belum diketahui secara pasti.

Penambahan vitamin C terhadap pakan komersial terbukti dapat meningkatkan sintasan secara signifikan setelah diuji tantang dengan KHV, hal ini mengindikasikan bahwa vitamin C mampu menginduksi kekebalan tubuh ikan terhadap infeksi KHV. Vitamin C hingga dosis tertentu dapat meningkatkan sistem pertahanan tubuh, di mana mekanismenya diduga adalah sebagai koenzim modulator melalui aktivasi cell mediated immunity (Navarre \& Halver, 1989; Ikeda, 1991; Robinson, 1991). Vitamin C juga berperan penting dalam pemeliharaan sistem kekebalan 
Tabel 1. Rataan persen sintasan ikan mas uji pasca uji tantang dengan koi herpes virus (KHV) selama 21 hari melalui teknik kohabitasi

Table 1. The mean percent of survival rate post-test carp challenge test with koi herpes virus (KHV) for 21 days using cohabitation technique

\begin{tabular}{lc}
\hline Penambahan vitamin C (Vitamin C addition) & Sintasan (Survival rate) (\%) \\
\hline A (Kontrol/Control) & $27.78^{\mathrm{a}}$ \\
B (250 mg/kg pakan/feed) & $70.00^{\mathrm{b}}$ \\
C (500 mg/kg pakan/feed) & $58.89^{\mathrm{b}}$ \\
D (750 mg/kg pakan/feed) & $82.22^{\mathrm{c}}$ \\
E (1,000 mg/kg pakan/feed) & $61.11^{\mathrm{b}}$ \\
\hline
\end{tabular}

Keterangan: Nilai rata-rata yang diikuti oleh huruf yang sama tidak berbeda nyata menurut uji jarak berganda Duncan pada selang kepercayaan $95 \%$

Description: The average values followed by the same letter are not significantly different according to Duncan's multiple range test at $95 \%$ confidence interval

yaitu membantu memelihara fungsi sel fagosit melalui peningkatan kegiatan kemotaktik netrofil dan makrofag serta mobilitas fagosit; dan kegiatan tersebut berpengaruh langsung terhadap pembentukan sel-sel fagosit. Melalui penambahan dosis vitamin $\mathrm{C}$ yang berbeda dalam pakan ikan trout yang diserang Infectious Hematopoifetic Necrosis (IHN) dihasilkan angka kematian dan tingkat kelangsungan hidup yang berbeda pada setiap penambahan vitamin C yang berbeda (Satyabudhy et al., 1990).
Perbedaan level protektif terhadap infeksi KHV pada ikan mas merupakan signal bahwa pada jumlah tertentu atau optimum vitamin $\mathrm{C}$ dapat memberikan manfaat yang maksimal, dan nilai tersebut secara eksperimental diperoleh pada penambahan vitamin C sebanyak 750 $\mathrm{mg} / \mathrm{kg}$ pakan. Berdasarkan nilai diferensial leukosit, pemberian imunostimulan pada dosis yang lebih tinggi tidak memberikan efek simultan terhadap peningkatan kekebalan nonspesifik. Hal ini sering terjadi dalam aplikasi imunologi, di mana pemberian antigen dalam

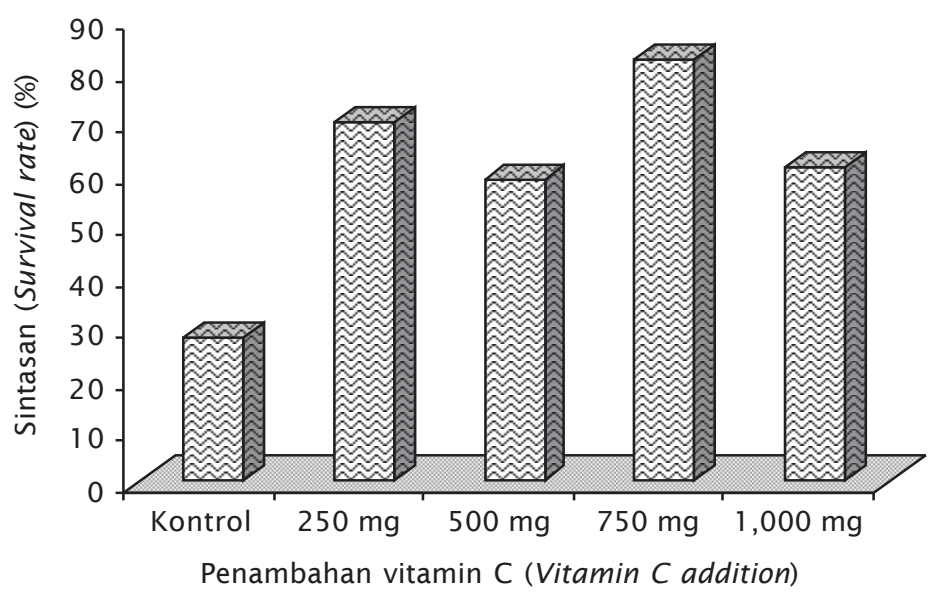

Gambar 4. Rataan persen sintasan ikan mas uji pasca uji tantang dengan Koi Herpes Virus (KHV) selama 21 hari melalui teknik kohabitasi

Figure 4. The mean percent of survival rate post-test carp challenge test with Koi Herpes Virus (KHV) for 21 days using cohabitation technique 
jumlah yang tidak optimal (terlalu rendah atau terlalu tinggi) dapat memberikan efek yang kurang baik dan bahkan dapat bersifat immunospressive, sehingga mengurangi atau bahkan menghilangkan efektivitasnya, meskipun antigen tersebut memiliki potensi imunogenik yang tinggi. Taukhid et al. (2000) mendapatkan bahwa pemberian imunostimulan (lipopolisakarida) secara intraperitoneal pada Rana catesbeiana sebanyak $50 \mathrm{mg} / \mathrm{ekor}$ diperoleh nilai aktivitas fagositik yang lebih tinggi dan stabil dibandingkan dengan kelompok yang diberi dosis lebih tinggi maupun kelompok kontrol.

Nilai rata-rata proporsi 4 jenis sel leukosit (limfosit, monosit, neutrofil, dan trombosit) yang diamati dari ikan uji selama 4 kali sampling disajikan pada Tabel 2, dan gambaran dari masing-masing sel leukosit tersebut dapat dilihat pada Gambar 5. Pada Tabel 2 terlihat bahwa proporsi jumlah sel limfosit dan neutrofil untuk kelompok perlakuan secara deskriptif menunjukkan nilai yang lebih tinggi dibandingkan dengan kontrol, sedangkan proporsi jumlah sel monosit dan trombosit menunjukkan hal yang sebaliknya, yaitu relatif tinggi pada kelompok kontrol dibandingkan dengan kelompok perlakuan.

Diferensial leukosit sering digunakan sebagai salah satu parameter hematologis untuk mengetahui status kesehatan dan kemampuan pertahananan tubuh (pertahanan

Tabel 2. Rata-rata proporsi nilai diferensial leukosit (limfosit, monosit, netrofil, dan trombosit) darah ikan uji pada minggu ke-0, 1, 2, dan 3 pasca infeksi buatan

Table 2. Average proportion of the value of differential leukocyte (lymphocyte, monocyte, neutrophil and thrombocyte) blood test fish at week 0, 1, 2, and 3 post-infection

\begin{tabular}{|c|c|c|c|c|}
\hline $\begin{array}{c}\text { Sampling } \\
\text { Dosis vitamin C ( Vit } \\
\text { C. sampling dose ) }\end{array}$ & $\begin{array}{c}\text { Limfosit } \\
\text { (Lymphocyte ) }\end{array}$ & $\begin{array}{c}\text { Monosit } \\
\text { (Monocyte ) }\end{array}$ & $\begin{array}{c}\text { Neutrofil } \\
\text { (Neutrophil ) }\end{array}$ & $\begin{array}{c}\text { Trombosit } \\
\text { (Trombocyte ) }\end{array}$ \\
\hline \multicolumn{5}{|l|}{ Ke-1(the first) } \\
\hline 250 mg/kg pakan (feed ) & $85.22 \pm 2.13$ & $5.51 \pm 137$ & $7.78 \pm 3.32$ & $149 \pm 0.49$ \\
\hline 500 mg/kg pakan (feed ) & $92.33 \pm 3.68$ & $4.33 \pm 2.56$ & $5.17 \pm 2.08$ & $0.17 \pm 0.28$ \\
\hline 750 mg/kg pakan (feed ) & $84.33 \pm 12.91$ & $6.5 \pm 5.68$ & $8.5 \pm 6.08$ & $0.67 \pm 115$ \\
\hline 1,000 mg/kg pakan (feed ) & $86.83 \pm 9.31$ & $6.83 \pm 5.6$ & $6.33 \pm 3.75$ & $0.00 \pm 0.00$ \\
\hline Kontrol (Control ) & $84.33 \pm 3.62$ & $7.67 \pm 126$ & $4.33 \pm 104$ & $3.67 \pm 189$ \\
\hline \multicolumn{5}{|l|}{ Ke-2 (the second) } \\
\hline 250 mg/kg pakan (feed ) & $84.99 \pm 6.23$ & $6.91 \pm 2.11$ & $4.8 \pm 2.33$ & $3.3 \pm 2.90$ \\
\hline 500 mg/kg pakan (feed ) & $92.5 \pm 7.5$ & $6.33 \pm 2.47$ & $5.0 \pm 2.18$ & $2.17 \pm 3.75$ \\
\hline 750 mg/kg pakan (feed ) & $89.0 \pm 3.61$ & $6.83 \pm 0.76$ & $8.17 \pm 0.76$ & $2.0 \pm 3.46$ \\
\hline 1,000 mg/kg pakan (feed ) & $90.5 \pm 3.28$ & $4.33 \pm 104$ & $6.17 \pm 153$ & $10 \pm 173$ \\
\hline Kontrol (Control ) & $8167 \pm 3.82$ & $7.5 \pm 5.41$ & $4.83 \pm 3.33$ & $6.0 \pm 5.07$ \\
\hline \multicolumn{5}{|l|}{ Ke-3 (the third) } \\
\hline 250 mg/kg pakan (feed ) & $86.23 \pm 2.12$ & $5.9 \pm 198$ & $4.98 \pm 2.2$ & $2.89 \pm 12$ \\
\hline 500 mg/kg pakan (feed ) & $90.17 \pm 4.25$ & $6.5 \pm 161$ & $5.67 \pm 189$ & $0.5 \pm 0.00$ \\
\hline 750 mg/kg pakan (feed ) & $88.33 \pm 12.05$ & $6.03 \pm 7.08$ & $7.33 \pm 2.93$ & $3.33 \pm 3.8$ \\
\hline 1,000 mg/kg pakan (feed ) & $89.67 \pm 7.51$ & $6.83 \pm 3.25$ & $5.33 \pm 4.01$ & $0.17 \pm 0.46$ \\
\hline Kontrol (Control ) & $82.5 \pm 9.64$ & $7.83 \pm 6.66$ & $5.0 \pm 5.57$ & $167 \pm 2.89$ \\
\hline \multicolumn{5}{|l|}{ Ke-4 (the fourth) } \\
\hline 250 mg/kg pakan (feed ) & $89.23 \pm 3.29$ & $5.2 \pm 2.22$ & $5.56 \pm 2.4$ & $0.1 \pm 0.00$ \\
\hline 500 mg/kg pakan (feed ) & $90.17 \pm 4.25$ & $6.5 \pm 161$ & $5.67 \pm 189$ & $0.5 \pm 0.00$ \\
\hline 750 mg/kg pakan (feed ) & $88.33 \pm 12.05$ & $6.03 \pm 7.08$ & $7.33 \pm 2.93$ & $3.33 \pm 3.8$ \\
\hline 1,000 mg/kg pakan (feed ) & $89.67 \pm 7.51$ & $6.83 \pm 3.25$ & $5.33 \pm 4.01$ & $0.17 \pm 0.46$ \\
\hline Kontrol (Control ) & $82.5 \pm 9.64$ & $7.83 \pm 6.66$ & $5.0 \pm 5.57$ & $167 \pm 2.89$ \\
\hline
\end{tabular}



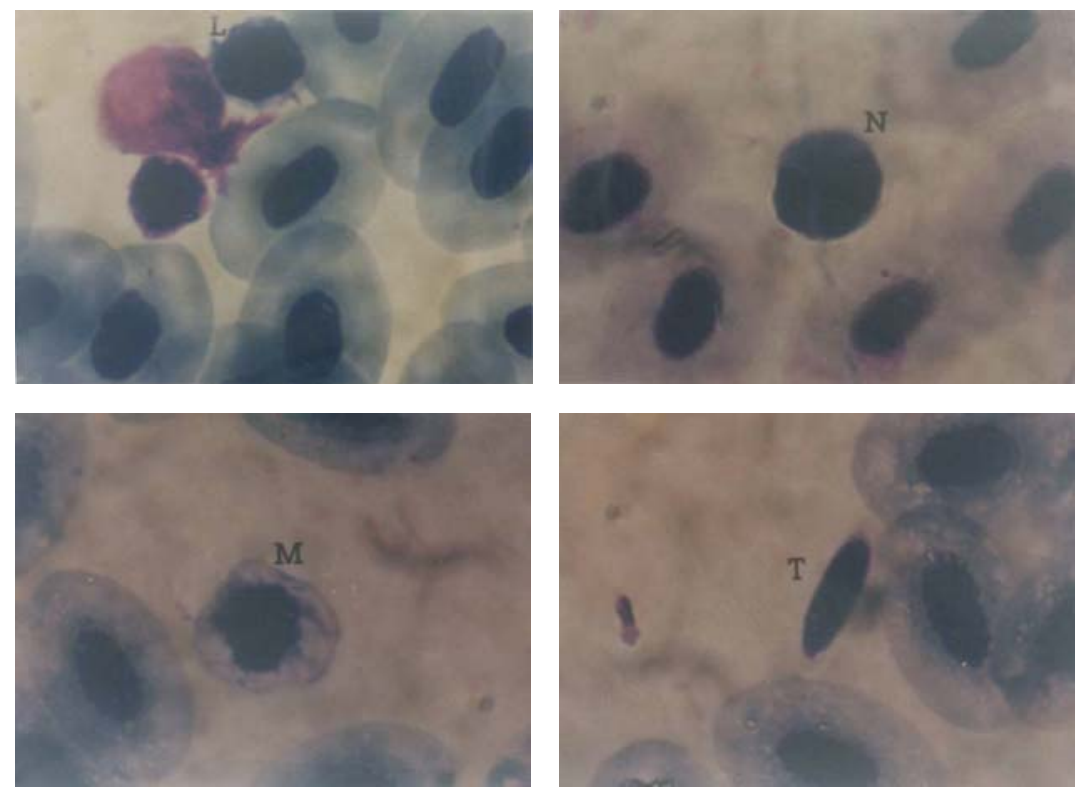

Gambar 5. Jenis-jenis leukosit pada ikan mas (Cyprinus carpio). Limfosit (L), Monosit (M), Netrofil (N), dan Trombosit ( $\mathrm{T}$ ) dengan pewarnaan giemsa pada pembesaran $1.000 \mathrm{x}$

Figure 5. The types of leucocytes in carp (Cyprinus carpio). Lymphocytes (L), Monocytes (M), Neutrophil (N), and Platelets (T) with Giemsa staining at 1,000 $\times$ magnification

seluler) terhadap infeksi jasad patogen. Sel limfosit berfungsi menyediakan zat kebal untuk pertahanan tubuh (Dellman \& Brown, 1989), ditemukan dalam jumlah yang cukup besar, meskipun pada saat infeksi terjadi penurunan. Peningkatan jumlah limfosit pada kelompok perlakuan (Tabel 2) diduga sebagai akibat dari pemberian vitamin $C$, hal ini sesuai dengan hipotesa Raa et al. (1992) bahwa pemberian imunostimulan akan menstimulir proses produksi lisosim dan komplemen yang akan mengaktifkan limfosit B untuk berdiferensiasi sehingga akan lebih aktif dalam memproduksi antibodi spesifik.

Fungsi utama neutrofil adalah penghancuran partikel asing termasuk patogen melalui proses fagositosis, yaitu kemotaksis di mana sel bermigrasi menuju partikel, perlekatan partikel pada sel, penelanan partikel oleh sel dan penghancuran partikel oleh enzim lisosim di dalam fagolisosom (Tizard, 1988). Keluarnya neutrofil dari pembuluh darah pada saat terjadinya infeksi disebabkan karena adanya pengaruh rangsangan kimiawi eksternal atau kemotaksis.
Peningkatan proporsi neutrofil pada kelompok perlakuan (Tabel 2) diduga akibat distimulasi oleh materi imunostimulan, sehingga aktivitas produksi oleh organ pembentuk sel tersebut kian meningkat. Pada mamalia, neutrofil merupakan sel fagositik dan akan nampak sangat cepat di sekitar tempat yang mengalami luka. Pada ikan yang mengalami luka akibat infeksi bakteri juga ditemukan adanya migrasi dan fagositosis oleh neutrofil dan sel makrofag (Finn \& Nielson, 1971).

Proporsi monosit dan trombosit didapatkan relatif rendah pada kelompok perlakuan dibanding dengan kontrol (Tabel 2), hal ini mungkin terjadi sebagai respon keseimbangan hematologi terhadap peningkatan proporsi sel leukosit jenis lainnya, yaitu limfosit dan neutrofil. Sel monosit diduga berperan sebagai sistem pertahanan kedua di mana sistem ini berlangsung lambat dan lama tetapi mampu melakukan fagositosis berulang-ulang (Tizard, 1988). Jumlah tombosit umumnya relatif hampir sama antara kelompok perlakuan dan kontrol (Tabel 2). Hal ini diduga karena tidak adanya 
Tabel 3. Nilai beberapa parameter kualitas air yang diamati setiap minggu

Table 3. The values of water quality parameters observed every week

\begin{tabular}{|c|c|c|c|c|c|c|c|c|c|c|}
\hline Sampling & $\begin{array}{c}\text { Perlakuan } \\
\text { (Treatment ) }\end{array}$ & $\mathrm{pH}$ & $\mathrm{O}_{2}$ & $\mathrm{CO}_{2}$ & $\begin{array}{l}\text { Alkalinitas } \\
\text { (Alkalinity) }\end{array}$ & Kesadahan & Amoniak & Nitrit & TOM & PO \\
\hline \multirow[t]{5}{*}{0} & $A$ & 7.0 & 6.07 & 5.19 & 90.24 & 74.88 & 0.038 & 3.23 & 19.57 & - \\
\hline & B & 8.0 & 6.63 & 2.79 & 90.24 & 70.72 & 0.038 & 3.23 & 19.87 & - \\
\hline & $\mathrm{C}$ & 7.5 & 6.07 & 4.39 & 97.18 & 62.40 & 0.032 & 2.76 & 20.81 & - \\
\hline & $\mathrm{D}$ & 7.0 & 6.99 & 5.19 & 104.12 & 70.72 & 0.071 & 3.23 & 27.02 & - \\
\hline & $\mathrm{E}$ & 7.5 & 5.89 & 3.95 & 104.12 & 66.56 & 0.024 & 3.23 & 26.09 & - \\
\hline \multirow[t]{5}{*}{1} & $A$ & 6.5 & 6.76 & 6.19 & 132.00 & 66.56 & 0.162 & 13 & 29.50 & 0.762 \\
\hline & B & 7.0 & 7.61 & 3.99 & 92.40 & 70.72 & 0.162 & 166 & 23.30 & 0.370 \\
\hline & C & 6.5 & 7.61 & 5.59 & 105.60 & 70.72 & 0.148 & 148 & 23.30 & 0.437 \\
\hline & D & 6.0 & 7.01 & 6.19 & 99.00 & 79.04 & 0.162 & 16 & 15.55 & 0.304 \\
\hline & $E$ & 6.5 & 7.01 & 6.39 & 85.80 & 70.72 & 0.107 & 181 & 6.20 & 0.239 \\
\hline \multirow[t]{5}{*}{2} & $A$ & 7.0 & 6.60 & 4.79 & 99.00 & 83.20 & 0.038 & 0.84 & 46.59 & 0.734 \\
\hline & $\mathrm{B}$ & 7.0 & 6.76 & 4.79 & 105.60 & 74.88 & 0.047 & 3.68 & 52.80 & 0.518 \\
\hline & C & 7.0 & 6.60 & 5.19 & 99.00 & 74.88 & 0.038 & 189 & 52.80 & 0.734 \\
\hline & $D$ & 7.0 & 5.76 & 5.59 & 99.00 & 79.04 & 0.050 & 189 & 57.46 & 0.677 \\
\hline & $E$ & 7.0 & 6.60 & 5.19 & 105.60 & 9152 & 0.038 & 174 & 43.48 & 0.714 \\
\hline \multirow[t]{5}{*}{3} & A & 7.5 & 8.30 & 3.20 & 99.00 & 70.72 & 0.030 & 0.42 & 27.95 & 2.520 \\
\hline & B & 7.5 & 9.67 & 2.80 & 99.00 & 66.56 & 0.032 & 0.34 & 22.05 & 2.140 \\
\hline & C & 7.5 & 7.83 & 4.39 & 92.40 & 70.72 & 0.032 & 0.61 & 27.64 & 3.300 \\
\hline & D & 7.5 & 7.83 & 4.79 & 85.80 & 54.08 & 0.041 & 0.65 & 27.33 & 2.140 \\
\hline & $E$ & 7.5 & 7.09 & 3.95 & 99.00 & 49.92 & 0.052 & 0.67 & 27.33 & 1910 \\
\hline \multirow[t]{5}{*}{4} & $A$ & 7.0 & 6.83 & 5.59 & 85.80 & 66.56 & 0.035 & 0.22 & 3105 & 2.140 \\
\hline & B & 7.0 & 7.14 & 5.59 & 85.80 & 66.56 & 0.047 & 0.59 & 3105 & 3.210 \\
\hline & C & 7.0 & 6.73 & 5.59 & 79.20 & 66.56 & 0.065 & 166 & 35.70 & 3.040 \\
\hline & D & 7.0 & 6.83 & 6.39 & 79.20 & 78.88 & 0.044 & 0.75 & 35.70 & 2.960 \\
\hline & $E$ & 7.0 & 7.14 & 6.39 & 92.40 & 66.56 & 0.059 & 13 & 43.50 & 2.810 \\
\hline \multirow[t]{5}{*}{5} & $A$ & 5.0 & 5.15 & 5.59 & 79.20 & 95.68 & 0.168 & 0.7 & 66.67 & 0.696 \\
\hline & B & 6.5 & 4.72 & 6.00 & 79.20 & 70.72 & 0.050 & 0.57 & 74.54 & 0.894 \\
\hline & C & 5.0 & 6.99 & 4.79 & 85.80 & 95.68 & 0.300 & 113 & 4193 & 0.338 \\
\hline & D & 6.0 & 4.78 & 7.19 & 72.60 & 79.00 & 0.409 & 0.5 & 45.06 & 0.392 \\
\hline & $E$ & 6.5 & 5.15 & 7.19 & 85.80 & 82.20 & 0.050 & 101 & 45.59 & 0.504 \\
\hline \multirow[t]{5}{*}{6} & $A$ & 4.5 & 7.04 & 3.79 & 85.80 & 9152 & 0.319 & 0.4 & 5127 & 1796 \\
\hline & B & 4.0 & 6.83 & 4.19 & 76.60 & 99.84 & 0.183 & 0.44 & 20.87 & 1850 \\
\hline & C & 5.0 & 6.25 & 4.19 & 105.60 & 99.84 & 0.239 & 154 & 17.77 & 1850 \\
\hline & D & 4.0 & 6.25 & 4.79 & 85.80 & 95.84 & 0.121 & 0.92 & 79.20 & 1962 \\
\hline & $E$ & 7.0 & 6.99 & 4.79 & 99.00 & 74.88 & 0.059 & 0.18 & 65.23 & 2.020 \\
\hline
\end{tabular}

ikan uji yang terluka. Seperti diketahui bahwa fungsi trombosit itu sendiri adalah untuk pembekuan darah saat terjadi luka dan mencegah kehilangan cairan tubuh pada kerusakan-kerusakan di permukaan kulit (Nabib \& Pasaribu, 1989), juga untuk menutup luka (Roberts, 1978).

Dasar pendekatan penggunaaan imunostimulan sebagai materi biologis untuk menginduksi kekebalan non-spesifik pada mulanya adalah untuk terapi kanker, karena materi tersebut diketahui mampu mengaktivasi sel makrofag, sel limfosit $T$ dan $B$, dan sel pembunuh alami; sehingga akan meningkatkan kemampuan tubuh untuk menghancurkan selsel tumor. Aktivitas tersebut juga akan meningkatkan ketahanannya terhadap infeksi jasad viral, bakterial dan parasitik (Azuma \& Jolles, 1987).

Hasil pengukuran parameter kualitas air yang meliputi: suhu, $\mathrm{pH}$, total bahan organik terlarut, kesadahan, ammonia, nitrit dan alkalinitas, diperoleh hasil seperti tertera pada Tabel 3. Pada tabel tersebut menunjukkan bahwa suhu air selama percobaan berada pada kisaran $24^{\circ} \mathrm{C}-28^{\circ} \mathrm{C}$. Parameter kualitas air 
lainnya secara umum masih dalam kisaran yang relatif baik bagi kehidupan ikan air tawar.

\section{KESIMPULAN}

Penambahan vitamin C pada pakan komersial dapat meningkatkan ketahanan tubuh ikan terhadap infeksi patogen. Penambahan vitamin C jenis CFC-90 (microencapsulated vitamin () pada pakan komersial sebanyak 750 $\mathrm{mg} / \mathrm{kg}$ pakan dan diberikan selama 14 hari berturut-turut, diperoleh sintasan ikan mas uji sebesar $82,22 \%$ setelah diuji tantang dengan $\mathrm{KHV}$, sedangkan rataan sintasan pada kelompok kontrol sebesar $27,78 \%$.

\section{UCAPAN TERIMA KASIH}

Riset ini dibiayai oleh DIPA Tahun Anggaran 2006 Balai Riset Perikanan Budidaya Air Tawar. Penulis mengucapkan terima kasih kepada Saudara Mikdarullah, Edy Farid, dan Bambang Priadi yang telah membantu pelaksanaan kegiatan ini baik di lapangan maupun di laboratorium.

\section{DAFTAR ACUAN}

Azuma, I. \& Jolles, G. 1987. Development of immunostimulants in Japan. In: Immunostimulants Now and Tomorrow. Japan Sci. Soc. Press, Tokyo and Spring Verlag, Berlin, p. 41-56.

Dellman, H.D. \& Brown, E.M. 1989. Buku teks histologi veteriner. Penerbit Universitas Indonesia. Jakarta, $279 \mathrm{hlm}$.

Direktorat Jenderal Perikanan Budidaya. 2002. Statistik Perikanan Budidaya Indonesia Tahun 2002. Jakarta, $127 \mathrm{hlm}$.

Finn, J.P. \& Nielson, N.O. 1971. The inflammatory of rainbow trout. J. Fish Biol., 3: 463478.

Gray, W.L., Mullis, L., LaPatra, S.E., Groff, J.M., \& Goodwin, A. 2002. Detection of koi herpesvirus DNA in tissues of infected fish. Journal of Fish Disease, 25: 171-178.

Ikeda, S. 1991. The crucial role of vitamin C in fish farming. Bulletin Gold Coin Aquaculture, 13(12): 1-13.

Jouncey, K., Soliman, A.K., \& Roberts, R.J. 1985. Ascorbic acid requirements in relation to wound healing in the cultured tilapia, Orechromis niloticus. Aquaculture Fish Manage, 16: 139-149.

Kamiso, H.N. 1996. Metode Pencegahan Hama dan Penyakit Ikan Karantina Dengan
Menggunakan Vaksin, Makalah disampaikan pada seminar Hama dan Penyakit Ikan Karantina. 13 Desember 1996. Cipanas Bogor, $18 \mathrm{hlm}$.

Lim, C. \& Lovell, T.R. 1978. Pathology of the vitamin C deficiency syndrome in channel catfish (Ictalurus punctatus). J. Nutr., 108: 1,137-1,148.

Lovell, T.R. 1982. Elevated levels of vitamin C increase disease resistance in channel catfish. Reprinted from Highlights of Agricultural Research, 29(1): 17-21.

Nabib, R. \& Pasaribu, F.H. 1989. Patologi dan Penyakit Ikan. Dep Dik Bud. Dirjen Pendidikan Tinggi. PAU Bioteknologi. IPB, hlm. 37-41.

Navarre, O. \& Halver, J.E. 1989. Disease resistance and humoral antibody production in rainbow trout fed high levels of vitamin $\mathrm{C}$. Aquaculture, 79: 207-221.

Ornamental Aquatic Trade Association (OATA). 2001. Koi Herpes Virus (KHV). OATA, Westbury, Wilts, UK, p. 4-33.

Raa, J. Roerstad, G., Engstad, R., \& Robertsen, B. 1992. The use of immunostimulants to increase resistance of aquatic organisms to microbial infections. In Diseases in Asian Aquaculture 1. Proceeding of the First Symposium on Diseases in Asian Aquaculture, 26-29 November 1990, Bali, Indonesia. (ed.by M. Shariff, R.P. Subasinghe and J.R. Arthur), Manila, Philippines, Fish Health Section, Asian Fisheries Society, p. 39-50.

Roberts, R.J. 1978. Fish pathology of fish. lowa State University Press, Ames, lowa, p. 310.

Robinson H. 1991. Deficiency sign and dietary requirement. Bulletin Gold Coin Aquaculture, 13: 12/91, p. 16-22.

Satyabudhy, A.M.A., Grtant, B.F., \& Halver, J.E. 1990. Pengaruh L-ascorbyl-2-phosphatase (AsPP) pada pertumbuhan dan ketahanan ikan rainbow trout (Onchorhynchus mykiss) terhadap infeksi virus. Prosiding Seminar Nasional II Penyakit Ikan dan Udang, 1618 Januari 1990. Bogor, hlm. 71-82.

Scombes, C.J. 1994. Enhancement of Fish Phagocyte Activity. Fish and Shellfish Immmunology, 4: 421-436.

Taukhid, Taufik, P., \& Mundriyanto, H. 2000. Respon kekebalan non-spesifik pada kodok benggala (Rana catesbeiana Shaw) terhadap pemberian imunostimulan (Lipopolisakarida, LPS). Paper hasil 
penelitian Balai Penelitian Perikanan Air Tawar Sukamandi T.A. 1999/2000 (tidak dipublikasikan).

Taukhid, Sunarto, A., Koesharyani, I., Supriyadi, \& Gardenia, L. 2004. Strategi pengendalian penyakit koi herpes virus (KHV) pada ikan mas dan koi. Makalah dipresentasikan pada Workshop pengendalian penyakit Koi Herpes Virus (KHV) pada budidaya ikan air tawar, Bogor 28 September 2004 (Tidak dipublikasikan).
Taukhid \& Suharni, I. 2005. Efektivitas ekstrak daun sambiloto, Andrographis paniculata bagi pengendalian penyakit koi herpes virus (KHV) pada ikan mas, Cyprinus carpio. Laporan teknis hasil riset perikanan budidaya air tawar (tidak dipublikasikan)

Tizard, I.R. 1988. An intoroduction to veterinary immunology. W.B. Saunders Company, Philadelphia, 285 pp. 